TRIBUTE

\section{Evan Weissman: Food studies scholar and hometown scholar-activist}

Special issue:

Food as a Tool for Social Change FALK $\mathbb{\substack { \text { Syracuse } \\ \text { University } }}$

\author{
Daniel R. Block* \\ Chicago State University
}

Submitted February 5, 2021 / Published online September 16, 2021

Citation: Block, D. R. (2021). Evan Weissman: Food studies scholar and hometown

scholar-activist. Journal of Agriculture, Food Systems, and Community Development, 10(4), 15-17. https://doi.org/10.5304/jafscd.2021.104.017

Copyright (C) 2021 by the Author. Published by the Lyson Center for Civic Agriculture and Food Systems. Open access under CC-BY license.

$\mathrm{I}$ $\mathrm{n}$ order to find a tenure-track job in their field, academics often must move far from their hometown and the university they graduated from. Evan Weissman was the rare academic who had the opportunity to stay at the university that granted him his Ph.D. and, even rarer, stay in his hometown of Syracuse, New York. He acknowledged the privilege of this situation in his remarkable article, "Privilege and Mistake Making in the Practice of Activist-Scholarship" (Weissman, 2018). In addition to stating his privilege as a white, male, able-bodied person, gainfully employed in a job that allowed him to follow his interests and do community-engaged work within the framework of academic freedom, he commented specifically on working in his hometown. He stated, "I am privileged to work and live in my hometown, where I have deep personal and political commitments. Because I live and work in my hometown, the traditional line between my identities and positions as community member and scholar are blurred" (Weissman, 2018, p. 1069). He went on to discuss the difficulty with attempting to be a scholar-activist without being seen as one or the other, particularly in a city such as Syracuse with an expensive private school located in a city with a large low-income population and a large degree of inequality, with a large town/gown separation.

I originally met Evan Weissman when he was a graduate student in the geography program at Syracuse. As a fellow geographer, activist-scholar, and food studies scholar, I actively followed his career. I later had the honor of serving as an outside reviewer for his tenure case, for which I explored his academic articles, his work as a teacher, and his service to his university, department, and community. Evan Weissman was the original hire in the Syracuse Food Studies program and focused much of his

* Daniel R. Block, Professor of Geography, Department of Geography, Sociology, History, and African-American Studies, Chicago State University; dblock@,csu.edu 
academic life on building the program and supporting its students. His academic position meshed with his deep commitment to the city of Syracuse. His teaching and writing bridged his activism, which focused on building a more equitable and sustainable food system in the Syracuse region, and predated his appointment to the Food Studies program. In 2007, he co-founded Syracuse Grows, a local food justice organization, and was heavily involved with a wide variety of food systems planning and food justice efforts in Syracuse (Hicks, 2020). His activist and academic worlds were difficult to separate. His Ph.D. was from the geography program at Syracuse, which is known for Syracuse Community Geography, a leading center for scholar-activist research, including work on food justice in the Syracuse area. He applied this training to academic and activist work, acting as a link between students, the Food Studies program, and the Syracuse food justice community, often integrating students into activist work and linking community organizations to university resources, for instance, in a study of mobile food markets in the Syracuse area (Robinson et al. 2016).

Evan Weissman's writings and everyday work were grounded in three characteristics that boosted his department and community: a strong devotion to his community and program; a combination of a critical perspective and a sense of kindness; and a sense of humility and introspection about his research. The idea that a food studies program could help boost both interdisciplinary cooperation within a university and cooperation between the university and community was prominently featured in an article describing the development of the Syracuse Food Studies program (Weissman et al., 2012). The combination of a critical perspective and kindness is apparent in much of his writing, particularly in his dissertation and a later article based on it, which focused on urban agriculture youth programming in Brooklyn, New York. Weissman argues that these programs in general follow accepted neoliberal pathways by focusing on job and entrepreneurship training. At the same time, many projects also include political organizing. Taken together, he is able to criticize the system in which both for-profit and not-for-profit urban agriculture projects must work within the neoliberal norms in order to survive, but also show empathy and respect for the programs that have to balance between liberation goals and the choice they make within the neoliberal U.S. economy (Weissman, 2015).

Perhaps the core of Evan Weissman's research philosophy was in turning a critical eye to his own work in addition to the work of others. His article "Privilege and Mistake Making in the Practice of Activist-Scholarship" is truly a great example of how to be an introspective yet humble scholar, working toward making actual improvements in people's lives. The article starts with Evan making an ill-advised joke during a presentation to a group of inner-city youth at a dairy farm. The reaction to this joke, as well as misconceptions he feels he had regarding youth interest in a photovoice project, point out to him his privileged position as a white man in Syracuse, as well as a professor and a leader in the local food movement. He then uses feminist scholarship to think about how he could do better, through reflexivity, awareness of his positionality, and promoting the voices of the community members he worked with (Weissman, 2018). Evan wrote about learning that his status as an experienced and accomplished professor and local food activist, and doing activist-scholarship in his hometown, had made him overconfident and lacking in understanding that despite his being a "local," the attitudes and experiences of the predominately Black youth he was working with were very different from his own.

Evan Weissman's gift was that he was able to see the issues in this work, act on them, do better, and continue to devote himself to activist-scholarship, to teaching and advising students, and to keep doing all of this with confidence. The combination of critical viewpoint, kindness, confidence, and humility he brought to the research he completed are great examples for both aspiring and experienced scholaractivists. His death is a huge loss to Syracuse and the greater community of food studies scholars. His work will continue to be studied by students and scholars for years to come. 


\section{References}

Hicks, M. (2020, April 27). Evan Weissman remembered for using academics to bring positive change. The Daily Orange. http://dailyorange.com/2020/04/evan-weissman-remembered-using-academics-bring-positive-change/

Robinson, J. A., Weissman, E., Adair, S., Potteiger, M., \& Villanueva, J. (2016). An oasis in the desert? The benefits and constraints of mobile markets operating in Syracuse, New York food deserts. Agriculture and Human Values, 33(4), 877-893. https://doi.org/10.1007/s10460-016-9680-9

Weissman, E. (2015). Entrepreneurial endeavors: (Re)producing neoliberalization through urban agriculture youth programming in Brooklyn, New York. Environmental Education Research, 21(3), 351-364. https://doi.org/10.1080/13504622.2014.993931

Weissman, E. (2018). Privilege and mistake making in the practice of activist-scholarship. ACME: An International Journal for Critical Geographies, 17(4), 1067-1084. https://acme-journal.org/index.php/acme/article/view/1511

Weissman, E., Gantner, L., \& Narine, L. (2012). Building a food studies program: On-the-ground reflections from Syracuse University. Journal of Agriculture, Food Systems, and Community Development, 2(3), 79-89.

https://doi.org/10.5304/jafscd.2012.023.010 